\title{
CEREBRAL BLOOD FLOW AND METABOLISM FOLLOWING KETAMINE ADMINISTRATION
}

\author{
Margaret Schwedler, David J. Miletich and Ronald F. Albrecht
}

\section{ABSTRACT}

The effects of ketamine on cerebral blood flow (CBF), cerebral metabolic rate $\left(\mathrm{CMRO}_{2}\right)$ and intracranial pressure (ICP) were evaluated in ventilated or spontaneously breathing goats after peripheral administration of $5 \mathrm{mg} \cdot \mathrm{kg}^{-1}$ and central administration of $0.1-2.0 \mathrm{mg}$.

In mechanically ventilated normocarbic goats intravenous ketamine $5 \mathrm{mg} \cdot \mathrm{kg}^{-1}$ had no effect on $\mathrm{CBF}$, but did produce a significant reduction in $\mathrm{CMRO}_{2}(4.3 \pm 0.4$ vs 3.7 $\pm 0.3 \mathrm{ml} \mathrm{O} \mathrm{O}_{2} \cdot \mathrm{min}^{-1} / 100 \mathrm{~g}$ ) five minutes after injection. However, in spontaneously breathing goats, ketamine caused a significant increase in CBF (77 \pm 7 vs $109 \pm$ $12 \mathrm{ml} \cdot \mathrm{min}^{-1} / 100 \mathrm{~g}$ ), a significant reduction in $\mathrm{CMRo}_{2}(4.3 \pm 0.3$ vs $3.8 \pm 0.4)$ and an increase of $\mathrm{PCO}_{2}$ from $4.5 \pm 0.5$ to $5.4 \pm 0.9 \mathrm{kPa}(34 \pm 4$ to $41 \pm 7$ torr). Small doses of ketamine $(0.1-2.0 \mathrm{mg})$ injected directly into the cerebral circulation failed to cause any significant change in $\mathrm{CBF}$.

Intracranial pressure showed a significant increase from $13 \pm 3$ to $19 \pm 3 \mathrm{~mm} \mathrm{Hg}$ in spontaneously breathing goats and no change in ventilated goats.

These data suggest that ketamine is a mild depressant of cerebral metabolic rate and has no other cerebral vascular effects.

Key WordS: ANAESTheTics, Intravenous, Ketamine: Brain, Cerebral blood flow, Cerebral metabolic rate, Intracranial pressure.

Though THE PREvaILING impression is that ketamine causes an increase in cerebral blood flow (CBF) and cerebral metabolic rate $\left(\mathrm{CMRO}_{2}\right)$, this impression is not supported by the literature. Indeed, considerable diametrically opposed results have been published on these subjects.

Ketamine has been reported to cause from an 80 per cent increase in CBF to a 50 per cent decrease. ${ }^{1,2}$ In addition, ketamine has been shown to have no effect on CBF. ${ }^{3}$ Dawson, et al. found a significant 16 per cent increase in $\mathrm{CMRO}_{2}$, while Kreuscher, et al. and Takeshita, $e t$ al. found insignificant decreases, $1,2,4$

Such variance in results is no doubt largely due to differences in methodology and the difficulty in measuring $\mathrm{CBF}$ and $\mathrm{CMRO}_{2}$ experimentally. The failure in some instances to control blood carbon dioxide may have contributed significantly to the confusion. The purpose of this study was to evaluate the effects of

Margaret Schwedler, M.D., Research Fellow; David J. Miletich, Ph.D. Assistant Professor; Ronald F. Albrecht, M.D., Professor and Chairman; Department of Anesthesiology, Michael Reese Hospital and Medical Center and Pritzker School of Medicine, University of Chicago, Chicago, Illinois 60616 , U.S.A.

Can. Anaesth. Soc. J., vol. 29, no. 3, May 1982 ketamine on $\mathrm{CBF}, \mathrm{CMRO}_{2}$, and intracranial pressure (ICP) in ventilated and spontaneously breathing goats following both central and peripheral administration of ketamine in subanaesthetic and anaesthetic does.

\section{METHODS}

Goats weighing 30 to $40 \mathrm{~kg}$ were anaesthetized with halothane and surgically prepared for continuous measurement of cerebral blood flow, as described by Miletich, et al. ${ }^{5}$ Briefly, during halothane-nitrous oxide anaesthesia an electromagnetic flow probe 4 or $5 \mathrm{~mm}$ in diameter was placed around an internal maxillary artery. In the goat the internal maxillary artery, a branch of the carotid artery, carries the entire blood supply to its respective half of the brain. Following this, a $2 \times 1 \mathrm{~cm}$ opening was made along the top and midline of the skull and a catheter was inserted into the superior sagittal sinus. The opening was then closed and the catheter was secured with dental cement. In addition, a Codman AccuFlow ventricular catheter (silicone, $1.3 \times 2.5 \times$ $150 \mathrm{~mm} x$-ray detectable) was chronically implanted into the left lateral cerebral ventricle and anchored to the skull with dental cement. Chron- 
TABLE I

Cardiovascular Effects of Ketamine in Non-paralyzed Goats

\begin{tabular}{|c|c|c|c|c|}
\hline & Control & $5 \min t$ & $10 \min \dagger$ & Recovery \\
\hline $\begin{array}{l}\text { Cerebral blood flow } \\
\left(\mathrm{ml} / 100 \mathrm{~g} \cdot \mathrm{min}^{-1}\right)\end{array}$ & $77 \pm 7$ & $109 \pm 12^{*}$ & $96 \pm 9^{*}$ & $88 \pm 9$ \\
\hline $\begin{array}{l}\text { Cerebral metabolic rate } \\
\left.\left(\mathrm{O}_{2} \mathrm{M}\right) / 100 \mathrm{~g}^{-1} \cdot \mathrm{min}^{-1}\right)\end{array}$ & $4.31 \pm 0.36$ & $3.82 \pm 0.27^{*}$ & $4.0 \pm 0.32 *$ & $4.12 \pm 25$ \\
\hline $\begin{array}{l}\text { Mean Arterial blood } \\
\text { pressure kPa (torr) }\end{array}$ & $\begin{array}{l}13.6 \pm 0.5 \\
(102 \pm 4)\end{array}$ & $\begin{array}{l}16.3 \pm 0.7^{*} \\
\left(123 \pm 5^{*}\right)\end{array}$ & $\begin{array}{l}15.9 \pm 0.8^{*} \\
\left(120 \pm 6^{*}\right)\end{array}$ & $\begin{array}{l}14.2 \pm 0.3 \\
(107 \pm 2)\end{array}$ \\
\hline $\mathrm{Pa}_{\mathrm{CO}_{2}} \mathrm{kPa}$ (torr) & $\begin{array}{l}4.5 \pm 0.5 \\
(34 \pm 4)\end{array}$ & $\begin{array}{l}5.4 \pm 0.9^{*} \\
\left(41 \pm 7^{*}\right)\end{array}$ & $\begin{array}{l}5.2 \pm 1.2^{*} \\
\left(39 \pm 9^{*}\right)\end{array}$ & $\begin{array}{l}4.5 \pm 1.1 \\
(34 \pm 8)\end{array}$ \\
\hline
\end{tabular}

Values represent mean $\pm \mathrm{SE}$

tMinutes after intrayenous ketamine $5 \mathrm{mg} \cdot \mathrm{kg}^{-1}$

*Significantly different from control values; $\mathrm{p}<0.05, \mathrm{n}=17$.

ic catheters were also implanted in both a femoral artery and a femoral vein for arterial blood pressure measurements and blood sampling. Upon completion of the surgical procedure each animal was permitted to recover for at least seven days before experimentation. Following recovery autoregulation was tested by intravenous injection of angiotensin $5 \mu \mathrm{g}$ (Hypertensin $\left.{ }^{*}\right)^{*}$ to insure that cerebral autoregulation was intact before animals were used for experimentation.

A total of 28 experiments were carried out in six goats. In 11 experiments the animals were paralyzed with gallamine $1 \mathrm{mg} \cdot \mathrm{kg}^{-1}$, quickly intubated and ventilated with room air. In the goat the trachea lies superficially on the neck and is easily palpated for rapid, painless intubation. Blood carbon dioxide concentrations were maintained at approximately $4.4 \mathrm{kPa}$ (33 torr) which has been reported as normal for goats. ${ }^{6}$ In 17 experiments, the goats breathed spontaneously.

Control values for CBF, ICP, $\mathrm{CMRO}_{2}$, mean aterial blood pressure (MABP) and blood gases were obtained in triplicate before ketamine was injected intravenously over a period of one minute. Cerebral blood flow, MABP, ICP, and blood gases were continuously monitored throughout each experiment. Before ketamine injection, 5 and 10 minutes after injection, and after emergence from anaesthesia (usually 45 minutes from the time of injection) $\mathrm{CMRo}_{2}$ was calculated from the femoral arterial and sagittal sinus oxygen content according to the formula

$\mathrm{CMRO}_{2}=(\mathrm{A}-\mathrm{V}) \mathrm{O}_{2} \times 2 \mathrm{CBF}:$ Brain weight.

After 10 minutes of ketamine anaesthesia cerebral autoregulation was tested once more with angiotensin $5 \mu \mathrm{g}$ injected intravenously.

*CIBA, Summit, N.J.
In four goats subanaesthetic doses (a dose too small to produce anaesthesia when injected peripherally) of ketamine 0.1-2.0 mg were injected directly into the cerebral circulation through a chronic temporal artery catheter. Cerebral blood flow, and MABP were monitored continuously during and following injection.

The methods of experimentation used throughout the study were determined by the Laboratory Animal Care Committee of Michael Reese Hospital and Medical Center to be ethical and not unnecessarily painful to the animals employed.

\section{RESULTS}

Intravenous injection of ketamine $5 \mathrm{mg} \cdot \mathrm{kg}^{-1}$ into normal awake goats caused immediate anaesthesia associated with a sudden rise in MABP and $\mathrm{Pa}_{\mathrm{CO}_{2}}$ (Table I). Shortly after these increases (usually one to two minutes) $\mathrm{CBF}$ began to increase reaching maximum values about 5 minutes after ketamine administration (Table I). Cerebral metabolic rate for oxygen decreased by approximately 11 per cent at five minutes and remained depressed until recovery from anaesthesia. Intracranial pressure increased significantly from a normal of $13 \pm 3$ to $19 \pm$ $3 \mathrm{~mm} \mathrm{Hg}(1.7 \pm 0.4$ to $2.5 \pm 0.4 \mathrm{kPa})$ at five minutes. Arterial oxygen concentrations fell significantly within five minutes following ketamine from $94 \pm 4$ to $82 \pm 7 \mathrm{~mm} \mathrm{Hg}(12.5 \pm 0.5$ to $10.9 \pm 0.9 \mathrm{kPa}$ ) and remained depressed until recovery.

Similar intravenous injections of ketamine into goats previously paralyzed with gallamine $1.0 \mathrm{mg} \cdot \mathrm{kg}^{-1}$ produced anaesthesia, but without significant increases in CBF (Table II). As seen in non-paralyzed goats, MABP rose significantly. However, because ventilation was controlled $\mathrm{PCO}_{2}$ concentrations remained stable 
TABLE II

Cardiovascular Effects of Ketamine in Paralyzed Goats

\begin{tabular}{|c|c|c|c|c|}
\hline & Control & $5 \min \dagger$ & $10 \min \dagger$ & Recovery \\
\hline $\begin{array}{l}\text { Cerebral blood flow } \\
\left(\mathrm{mL} / 100 \mathrm{~g} \cdot \mathrm{min}^{-1}\right)\end{array}$ & $68 \pm 4$ & $62 \pm 5$ & $65 \pm 5$ & $61 \pm 6$ \\
\hline $\begin{array}{l}\text { Cerebral metaolic rate } \\
\left.\left(\mathrm{O}_{2} \mathrm{M}\right) / 100 \mathrm{~g}^{-1} \cdot \min ^{-1}\right)\end{array}$ & $4.34 \pm 0.39$ & $3.71 \pm 0.33^{*}$ & $4.05 \pm 0.36$ & $4.32 \pm 0.45$ \\
\hline $\begin{array}{l}\text { Mean Arterial blood } \\
\text { pressure kPa (torr) }\end{array}$ & $\begin{array}{l}13.8 \pm 4 \\
(104 \pm 3)\end{array}$ & $\begin{array}{l}15.2 \pm 4 \\
\left(114 \pm 3^{*}\right)\end{array}$ & $\begin{array}{l}15.6 \pm 0.5^{*} \\
\left(117 \pm 4^{*}\right)\end{array}$ & $\begin{array}{l}15.4 \pm 0.5^{*} \\
\left(116 \pm 4^{*}\right)\end{array}$ \\
\hline $\mathrm{Pa}_{\mathrm{CO}_{2}} \mathrm{kPa}$ (torr) & $\begin{array}{l}4.2 \pm 0.1 \\
(32 \pm 0.9)\end{array}$ & $\begin{array}{l}4.0 \pm 0.2 \\
(30 \pm 1.2)\end{array}$ & $\begin{array}{l}4.0 \pm 0.2 \\
(30 \pm 1.3)\end{array}$ & $\begin{array}{l}3.8 \pm 0.2 \\
(29 \pm 1.5)\end{array}$ \\
\hline
\end{tabular}

Values represent mean $\pm S E$.

$\dagger$ Minutes after intravenous ketamine $(5 \mathrm{mg} / \mathrm{kg})$.

*Significantly different from control values; $\mathrm{p}<0.05, \mathrm{n}=11$.

(Table II). As in non-paralyzed goats, $\mathrm{CMRO}_{2}$ decreased approximately 15 per cent until recovery. Intracranial pressures were unchanged by ketamine injection.

Subanaesthetic doses of ketamine $(0.1-2.0$ $\mathrm{mg}$ ) injected through the temporal artery directly into the cerebral circulation of unanaesthetized paralyzed goats failed to produce any significant change in $\mathrm{CBF}$.

\section{Discussion}

In paralyzed ventilated goats intravenous ketamine $5 \mathrm{mg} \cdot \mathrm{kg}^{-1}$ did not produce any significant change in ICP, or CBF (Table II). Correspondingly, central injections of subanaesthetic doses into the cerebral vascular system did not alter $\mathrm{CBF}$, indicating that ketamine has no immediate or direct effect on cerebral vessels. This observation is in contrast to the conclusion from the studies by Ivankovich, et al. using the same animal model, that administration of ketamine does increase CBF. ${ }^{7}$ This conclusion, however, seems unwarranted in that no $\mathrm{CBF}$ changes were evident for up to at least one minute following central ketamine administration. One would expect that CBF changes should have occurred within seconds if a direct vascular mechanism were involved. Since this was not seen, it may mean that the observed increases in CBF were the secondary result of increases in $\mathrm{Pa}_{\mathrm{CO}_{2}}$ and arterial blood pressure. Indeed, data from our studies in non-paralyzed goats show significant increases in CBF occurring coincident with elevations in $\mathrm{PaCO}_{2}$ and arterial blood pressure.

Takeshita, et al. reported an increase in CBF with no significant change in $\mathrm{CMRO}_{2}$ in patients free of cardiopulmonary or neurological compli- cations. ${ }^{4}$ However, it is difficult to judge at what point in the study CBF determinations were made in these patients. In our experiments, the maximum effect of ketamine on CBF and $\mathrm{CMRO}_{2}$ occurred approximately five minutes after administration. Assuming the same to be true in man, $\mathrm{CBF}$ and/or $\mathrm{CMRO}_{2}$ determinations made much after five minutes might represent emerging or recovered values. In addition, Takeshita, et al. made no attempt to determine the status of cerebral autoregulation. Without an intact autoregulatory mechanism, the steep increases in arterial blood pressure seen by these authors could have contributed to, or caused the CBF elevations following ketamine.

Similar perplexing variables confuse the work of Hougaard, et al. ${ }^{3}$ In patients with various kinds of cerebral vascular impairment, total and regional CBF were studied 2-4 minutes following ketamine administration. Only two of five patients showed an increase in total CBF. However, four of five patients did have an increase in flow to the frontotemporal region. The authors concluded that regional $\mathrm{CBF}$ increases after ketamine were due to local cerebral metabolic changes and not to direct vascular effects. But these conclusions were based on only two patients, one of whom had a simultaneous increase in MABP above the normal cerebral autoregulatory range. Likewise, both total and regional CBF changes seen throughout this study correlated well with changes in MABP. As in the previous studies, one might wonder about the intactness of the cerebral autoregulatory capability, particularly in patients with cerebral vascular impaiment.

Dawson, et al. found in dogs that intravenous ketamine administration caused approximately 80 per cent increase in CBF along with a modest 
16 per cent increase in $\mathrm{CMRO}_{2} .{ }^{\prime}$ Unfortunately, control MABP values were inordinately high, almost exceeding the upper cerebral autoregulatory range for dogs. Even the moderate increases in MABP seen by Dawson, et al. at this time could easily have exceeded the autoregulatory range, adding to CBF values.

It seems to be well documented that ketamine causes an increase in ICP in patients with space occupying lesions. ${ }^{8,9}$ However, in patients with normal spinal fluid pathways results are less clear. Gardner, et al. ${ }^{10}$ reported a large increase in ICP in their normal subjects, while Gibbs saw no significant change. ${ }^{11}$ Interpretation of these divergent results may be facilitated by recent studies in which it was seen that ketamine administration to patients caused considerable alteration in pulmonary haemodynamics and gas exchange. ${ }^{12,13}$ In our study ICP and CBF changes occurred only in animals with unaided ventilation. Thus it is possible that large ICP changes reported during ketamine anaesthesia may be due to the effects of ketamine on the pulmonary circulation rather than on cerebral haemodynamics.

In conclusion, it would seem that much of the contradictory data concerning the direct effects of ketamine on $\mathrm{CBF}, \mathrm{ICP}$, and $\mathrm{CMRO}_{2}$ might be due chiefly to methodological limitations and deficiencies of previous studies. While ketamine has been shown to have sympathomimetic properties, no studies to date have shown it to have direct vascular or metabolic effects in other organs. ${ }^{14}$

\section{ACKNOWLEDGEMENTS}

Sincere appreciation is extended to Ms. C. Seals, Ms. A. Jozefiak, and Mr. D. Visintine for their help in completing this study.

1. Dawson, B., Michenfelder, J.B. \& Theye, R.A. Effects of ketamine on canine cerebral blood flow and metabolism: Modification by prior administration of thiopental. Anesth. Analg: 50: 443 (1971).

2. Kreuscher, H \& Grote J. Die wirkung des phencyclidin - derivates ketamine (CI581) auf die durchblutung und saures - stoffaufnahme des gehirns bein hund. Der Anaesthesist 16: 304 (1967).

3. Hougatid, K. hansen A. \& Broderson P. The effect of ketamine on regional cerebral blood flow in man. Anesthesiology 41: 562 (1974).

4. TAKeShita, H., OKUDA, Y. \& SaR $A$. The effects of ketamine on cerebral circulation and metabolism in man. Anesthesiology 36: 69 (1972).

5. Miletich, D.J., Ivankovich, A.D., ALBRECHT, R.F., et al. Cerebral hemodynamics following internal maxillary artery ligation in the goat. J. Appl. Physiol. 38: 942 (1975)

6. Reimann, C., Lluch, S. \& Glick, G. Development and evaluation of an experimental model for the study of the cerebral circulation in the unanesthetized goat. Stroke 3: 322 (1973).

7. Ivankovich, A.D., Miletich, D.J., Reimann, C., et al. Cardiovascular effects of centrally administered ketamine in goats. Anesth. Analg. 53: 924 (1974).

8. Shapiro, H.M., Wyte, S.R. \& Harris, A.B. Ketamine anaesthesia in patients with intracranial pathology. Brit. J. Anaesth. 44: 1200 (1972).

9. Wyte, S.R., Shapiro, H.M., TURner, P., et al. Ketamine induced intracranial hypertension: two case reports. Anesthesiology 36: 174 (1972).

10. Gardner, A.E., Olson, B.E. \& Lichtiger, M. Cerebrospinal-fluid pressure during dissociative anesthesia with ketamine. Anesthesiology 35: 226 (1971)

11. GIBBS, J.M. The effect of intravenous ketamine on cerebrospinal fluid pressure. Brit. J. Anaesth. 44: 1298 (1972)

12. Gooding, J.M. Dimick, A.R., Tavakoll, M. et al. A physiologic analysis of cardiopulmonary responses to ketamine anesthesia in noncardiac patients. Anesth. Analg. 56: 813 (1977).

13. Waxman, K., Shogmaker, W.C. \& Lippman, M. Cardiovascular effects of anesthetic induction with ketamine. Anesth. Analg. 59: 355 (1980).

14. Miletich, D.J., IVANKovich, A.D., ALBRECHT, R.F., et al. The effect of ketamine on catecholamine metabolism in the isolated perfused rat heart. Anesthesiology 39: 271 (1973).

RÉsumé

Les effets de la kétamine administrée par voie intraveineuse à la dose de $5 \mathrm{mg} \cdot \mathrm{kg}^{-1}$ ainsi que ceux produits par l'administration directe d'une petite dose $(0.1$ à $2 \mathrm{mg})$ de cet agent dans l'artère temporale faisaient l'objet de cette étude effectuée chez la chèvre. Les paramètres mesurés étaient le débit sanguin cérébral, le métabolisme cérébral et la pression intracranienne. Dans onze des cas, l'étude a été faite chez l' animal en respiration spontanée, alors que la ventilation était contrôlée dans dix-sept autres cas.

Chez la chèvre en respiration contrôlée (avec maintien d'une $\mathrm{PCO}_{2}$ normale), l'administration intraveineuse de $5 \mathrm{mg} \cdot \mathrm{kg}^{-1}$ de kétamine ne modifiait pas le débit sanguin cérébral, mais une diminution significative du métabolisme cérébral $\left(4.3 \pm 0.4\right.$ vs $3.7 \pm 0.3 \mathrm{ml} \mathrm{O} \mathrm{O}_{2}$. $\min ^{-1}$ par $100 \mathrm{~g}$ ) était observée cinq minutes après l'injection. 
Chez l'animal en respiration spontanée, la même dose de kétamine amenait une augmentation significative du débit sanguin cérébral qui passait de $77 \pm 7$ à $109 \pm$ $12 \mathrm{ml} \cdot \mathrm{min}^{-1} / 100 \mathrm{~g}$; cette dose causait également une diminution significative du métabolisme cérébral $\left(4.3 \pm 0.3\right.$ vs $3.8 \pm 0.4 \mathrm{ml} \mathrm{O}_{2} \cdot \mathrm{min}^{-1} / 100 \mathrm{~g}$, ainsi qu'une élévation de la $\mathrm{PCO}_{2}$ qui passait de $4.5 \pm 0.5$ à $5.4 \pm 0.9 \mathrm{kPa}$ ( $34 \pm 4$ à $41 \pm 7$ torr).

De petites doses de kétamine ( 0.1 a $2 \mathrm{mg}$ ) injectées directement dans la circulation cérébrale ne modifiaient pas de façon significative le débit sanguin cérébral.

Une élévation significative de la pression intracranienne (qui passait de $13 \pm 3$ à $19=$ $3 \mathrm{mmHg}$ ) a été observée chez lez chèvres en respiration spontanée, alors qu'aucun changement n'était observé chez les animaux en ventilation contrôlée.

Ces résultats suggèrent que la kétamine est un dépressant léger du métabolisme cérébral sans autres effets vasculaires cérébraux. 